\title{
PERSONNEL WORK LIFE QUALITY AND ENGAGEMENT: EXAMPLE OF A NORDIC BUSINESS INFORMATION TECHNOLOGY COMPANY
}

\author{
Solveiga Blumberga \\ RISEBA, Latvia \\ Dace Akmene \\ RISEBA, Latvia
}

\begin{abstract}
Work life quality and engagement have been widely studied and terms are being used in the context of working life. Together these terms have not been studied much. Although the connection between these two has been proven as significant in various researches. The aim of every company is to perform well and make a profit, or just one of these aims depending on the type of enterprise and their business. The aim of the research is to determine personnel work life quality and work engagement, their differences, and interconnection in a Nordic business information technology company's division in Latvia and Finland. Three research questions were set: What is the evaluation of personnel work life quality and work engagement; Is there a statistically significant connection between personnel work life quality and work engagement; Are there statistically significant differences in results of work life quality and work engagement in a Nordic business information technology company's divisions in Latvia and Finland. The following methods were used for data acquisition: work life quality questionnaire; Work engagement questionnaire. Analysis of the results showed that the evaluation of work life quality and work engagement is medium-high. There is a statistically significant correlation between work life quality and work engagement. Statistically significant differences were found between personnel work life quality and work engagement in both countries. Various work life quality factors promote work engagement. For both divisions, the most challenging is balancing work and private life of the employees. Employees in Finland would evaluate the company's inner communication higher if they felt more engaged in decision making. Researches of differences reveal that employees of Latvian companies show higher results in social integration and employer and company evaluation than personnel in Finland.
\end{abstract}

Keywords: work life quality, engagement.

\section{Introduction}

Work is, has been and will be an important part of people's lives. It should be noted that with time amount of working hours per week has increased in comparison to, for example, 50 years ago (Connolly et al., 2017). Working a fulltime job people are subjected to various aspects of work life that influence their lives both at work and outside it. 
Blumberga \& Akmene, 2020. Personnel Work Life Quality and Engagement: Example of a Nordic Business Information Technology Company

Work life quality and engagement are widely studied terms in the context of work life. Work life quality is a term that includes various conditions determining the quality of work life. This notion shows to what extent employees can meet their personally important needs while being employed (Srivastava \& Kanpur, 2014). Work life quality can also be viewed as a strategy with the help of which to retain employees and increase their job satisfaction (Monga \& Verma, 2015). Whereas engagement is a term that characterizes the employee's attitude and emotional state towards their work and employer. Or emotionally - a motivated state of elevated energy in combination with high keenness and level of work focus (Bakker \& Albrecht, 2018).

Together these terms have not been studied much. Nevertheless, the relation between both terms has been proven as significant in various studies (Kanten \& Sadullah, 2012; Alqarni, 2016). The topicality of the subject is determined by the fact that the company concentrates on the promotion of engagement and research. Considering that different companies show diverse engagement indicators, it is necessary to understand what the main reasons for the difference in the evaluation are. Work life quality factors have not been studied separately which will give the possibility to overview and analyze opinions of employees on this topic.

Researching work life quality in the companies and its connection to engagement will show the most important aspects of work life quality to summarize them and give recommendations. Three research questions were set: What is the evaluation of personnel work life quality and work engagement; Is there a statistically significant connection between personnel work life quality and work engagement; Are there statistically significant differences in results of work life quality and work engagement in a Nordic business information technology company's divisions in Latvia and Finland.

The aim of the research is to study work life quality and engagement and to develop suggestions for HR on promoting work life quality and engagement. Latvian companies regularly show higher, but Finnish companies lower results as the median score of the company. That is why it was decided to include both these countries that regularly show the highest and lowest results in work engagement studies.

\section{Literature Review}

Considering the importance of work life quality, it is being evaluated as one of the most significant work aspects (Kawemba, 2010). Many authors for analysis and study of work life quality have chosen Walton's eight conceptual categories, namely: adequate and fair compensation; safe and healthy working conditions; use and development of human capacity; opportunity for continued growth and security; social integration at work; constitutionalism in work organization; work 
and life space; social relevance of work life (Walton, 1973). Work life quality works at the same time both for employee's higher and basic needs (Srivastava \& Kanpur, 2014) as indicated by scope of different needs in Walton's categories.

Work itself is an important part of work life quality. Work must be wider including varied duties so that the employee would not spend long time on one specific task (Srivastava \& Kanpur, 2014). Companies without strict duties indicate to applying this aspect in real action. It is also a good approach to do employee rotation giving them chance to do completely different tasks thus developing their skills and competencies (Srivastava \& Kanpur, 2014).

Work life quality is considered as philosophy, a set of principles based on the concept that people are the most important resource of the company (Reddy \& Reddy, 2010). Such approach indicates to necessity of work life quality programma, organization's understanding about different factors and implementation strategy. Irrespective of where work life quality programmas are developed: from management, employees or outsourced, these programmas prove to be successful in various manifestations (Dixit \& Pandiya, 2015). Work life quality programmas give support in recruitment, encourage retention, increase productivity, decrease absence and maximize use of human resource (Inda, 2013).

Engagement is a topical term among researchers and HR professionals who consider this concept as one of the main promoters of success in companies (Ababneh \& Macky, 2015). High levels of engagement promote talent retention, contribute to client loyalty and improve company's performance (Lockwood, 2007). In the context of work importance, engagement is one of the main factors together with job satisfaction, autonomy, work relations and continuing education (Geldenhuy, Laba, \& Venter, 2015). Definition of engagement overlaps with the one of involvement which indicates to that often employees are more involved with their work rather that their employer (Armstrong, 2006). Committed employees perform $20 \%$ better and are $87 \%$ less likely to leave the company (Corporate Leadership Council, 2004), not considering if employees are committed to their work or their employer.

Work-place culture determines the tone of engagement (Lockwood, 2007). Disengaged employees are not interested in generating new ideas or suggesting creative solutions; whereas engaged employees consider creativity as part of their job and generate new ideas and approaches (Sharma, Chaudhary, \& Singh, 2018). Often the age, function and position of the employee is linked with engagement, but it has been proven that it does not determine level of engagement. Levels of engagement are more determined by company's strategies and policies rather than characteristics of employees (Corporate Leadership Council, 2004). Level of employee engagement directly indicates to their feelings about their manager (Redmond, 2009). Managers have a crucial role in enabling and promoting engagement (Corporate Leadership Council, 2004). Viewing work life quality and 
Blumberga \& Akmene, 2020. Personnel Work Life Quality and Engagement: Example of a Nordic Business Information Technology Company

engagement as a whole, work life quality is being set as basis that determines level of engagement and job satisfaction (Fatmasari, Mochammad, \& Wulida, 2018).

\section{Methodology}

\section{Sample:}

In the companies included in the research, there are 334 employees, 188 of which working in Latvia and 146 in Finland. Altogether 174 replies were gathered, 103 respondents from Latvia and 71 respondents from Finland. Gender balance among respondents is equal: $48 \%$ women and $52 \%$ men. The main part of respondents, $44 \%$, were aged 25 to 34 years, $31 \%$ - aged 35 to 44 years. In the age group 45 to 54 years there were $9 \%$ of respondents but in the age groups 18 to 24 years and 55 and more $-8 \%$ each.

\section{Measure:}

Work life quality questionnaire (Walton, 1973; Timossi et al., 2008). Four categories were chosen for the questionnaire: safe and healthy working conditions, use and development of human capacity, social integration at work, work and living space. Statements were taken from Timossi (Timossi et al., 2008) questionnaire based on Walton's eight categories.

Work engagement questionnaire (Schaufeli \& Bakker, 2004; Corporate Leadership Council, 2004). The second part of the questionnaire consists of work engagement statements developed based on UWES approach (Schaufeli \& Bakker, 2004) using three statements on engagement levels: energy, diligence, and keenness. Additional to these statements there were more statements to evaluate engagement based on engagement promoting factors developed in another research (Corporate Leadership Council, 2004). In both questionnaires' questions were adapted to the companies and research needs, all statements had to be evaluated using 4-point Likert scale: disagree, rather disagree, rather agree, agree. The questionnaire was developed in Latvian and English.

\section{Procedure:}

Before the acquisition of research data, a pilot research was done where Cronbach's alpha was verified, and it was above 0.7. Taking into consideration the coefficient, authors of the research changed the questionnaire resulting in repeated calculation of Cronbach's alpha, getting above 0.8. Data was gathered from 1st to 12th April 2019. Questionnaires were published and data gathered on Webtool.

\section{Research results}

Looking at work life quality statement groups (Figure 1), one can see that employees are the most satisfied with social integration at work. Considering 
statements under this group, it can be concluded that employees feel belonging both to the company and their teams. Also, their ideas are taken into account and they participate in events organized by the company. Work stress influences the private lives of employees and some employees cannot rest not thinking about work, which explains lower evaluation of work and living space statement group. There are no statistically significant differences between the statement groups, however, there is a tendency for differences. This applies to the work life quality statement groups as well as for the work engagement statement groups.

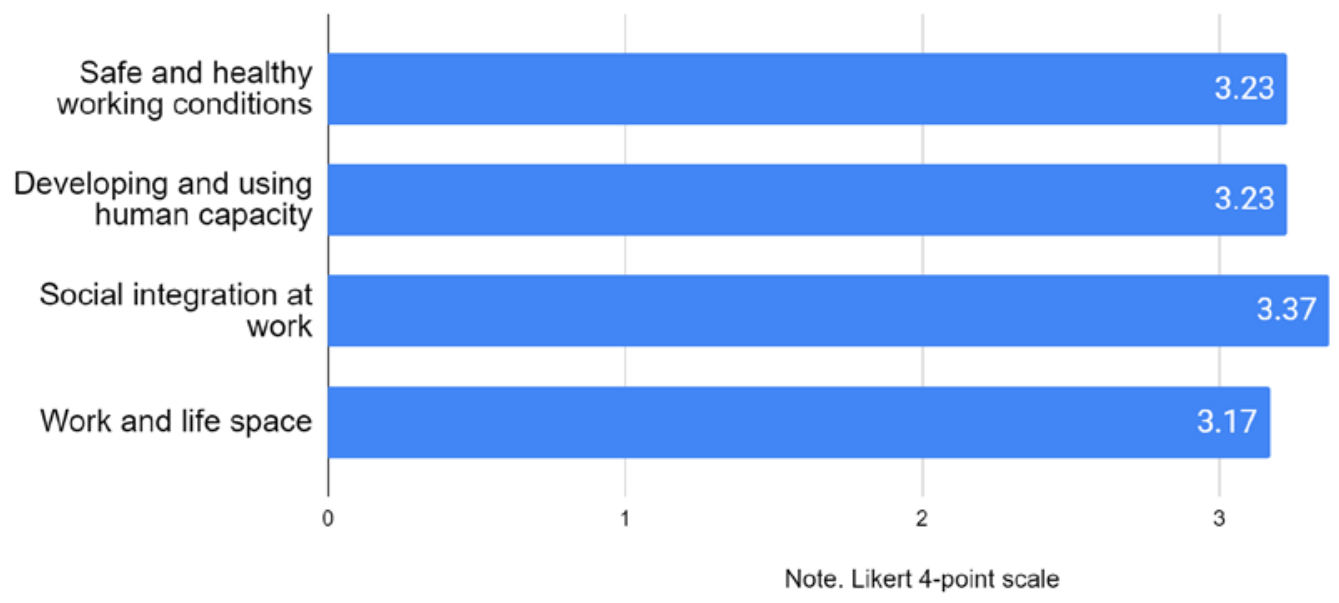

Figure 1 Evaluation of work life quality scales

Whereas in statement group on work engagement (Figure 2) highest evaluations were given to statements about colleagues, but lower - about company and managers. Employees like to work with their colleagues and they mostly have good relationships with at least one colleague. Regarding company and managers employees state that at times they do not like internal communication. This statement can be connected with another statement with lower evaluation about that company does not involve employees in decision making.

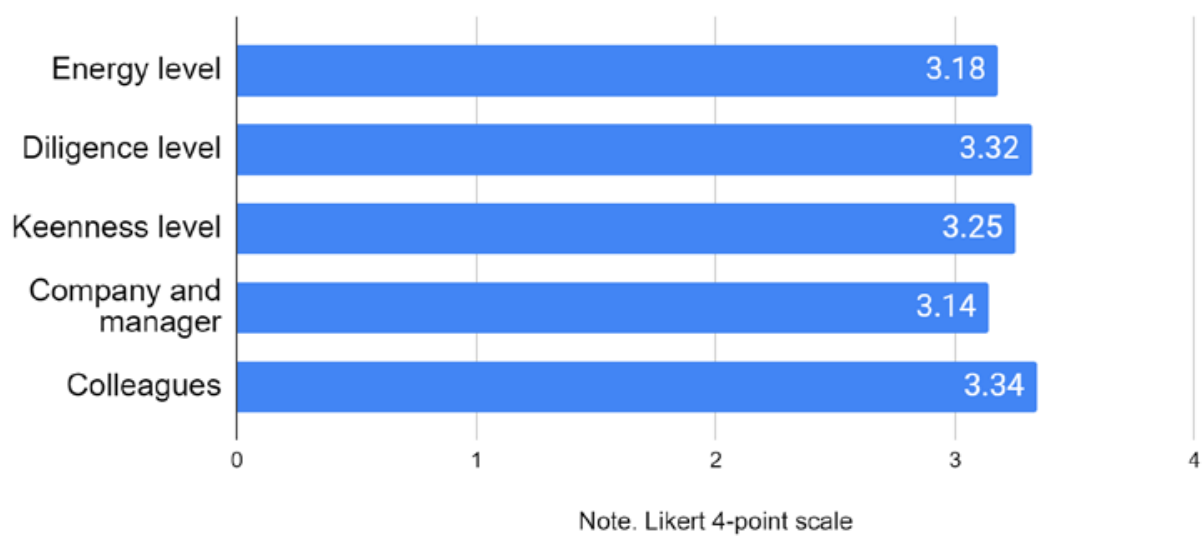

Figure 2 Evaluation of work engagement scales 
Blumberga \& Akmene, 2020. Personnel Work Life Quality and Engagement: Example of a Nordic Business Information Technology Company

Performing Spearman's correlation (test distribution is not normal) on work life quality and engagement indicators (Table 1) it was established that there is a statistically significant correlation between them $(\mathrm{r}=.64 ; \mathrm{p}=.00)$. This correlation proves previously viewed statement groups which corresponds to high evaluation of social integration and positive evaluations about colleagues. It also explains lower evaluation of statements about company and manager and work load of employees which influences their private lives. Employees being in more stress would not be satisfied with their company and manager. Nevertheless, it should be noted that company and manager make social integration of employees, use and develop human capacity and other positive manifestations.

Table 1 Spearman's correlation of work life quality and engagement

\begin{tabular}{|c|c|}
\hline Measure & Engagement \\
\hline Work life quality & $.644^{* *}$ \\
\hline
\end{tabular}

Note. $N=174 . * * p<.01$

Spearman's correlation was done also to separate scales and the results showed that there is a statistically significant correlation among all scales. Scales with the highest correlation coefficients (Table 2) are Social integration at work and Company and manager $(\mathrm{r}=.61 ; \mathrm{p}=.00)$, Company and manager and Use and development of human capacity $(\mathrm{r}=.60 ; \mathrm{p}=.00)$.

Table 2 Highest correlations in work life quality and engagement scales

\begin{tabular}{|l|c|c|}
\hline \multicolumn{1}{|c|}{ Measure } & Company and manager & Diligence level \\
\hline Safe and healthy work conditions & $.499^{* *}$ & $.398^{* *}$ \\
\hline Use and development of human capacity & $.597^{* *}$ & $.528^{* *}$ \\
\hline Social integration at work & $.613^{* *}$ & $.383^{* *}$ \\
\hline
\end{tabular}

Note. $N=174 .{ }^{* *} p<.01$

Mann-Whitney $U$ test was done to clarify scales where there were statistically significant differences between both countries. Results show (Table 3) that main differences are in scales of Social integration at work $(\mathrm{U}=2111.5 ; \mathrm{p}<.00)$, Company and manager $(\mathrm{U}=2277.5 ; \mathrm{p}<.00)$ and Use and development of human capacity $(\mathrm{U}=2323.5$; $\mathrm{p}<.00)$. 
Table 3 Mann-Whitney $U$ test for statistically significant scales between countries

\begin{tabular}{|l|c|}
\hline & U-criterion \\
\hline Safe and healthy working conditions & 2912.5 \\
\hline Use and development of human capacity & 2323.5 \\
\hline Social integration at work & 2111.5 \\
\hline Diligence level & 2954.5 \\
\hline Company and manager & 2277.5 \\
\hline
\end{tabular}

Note. $N=174$

Considering differences in median values of Latvian and Finnish scales, there is a noticeable difference (Figure 3). Evaluations of Company and manager are much lower of employees of Finnish companies than Latvian personnel indicating that this aspect is problematic in Finland. Social integration at work is much higher in Latvia, which can be explained with employees wish to participate in event planning and attending them. In Finland lower evaluation is also given to Use and development of human capacity which might explain lower evaluation of Company and manager.

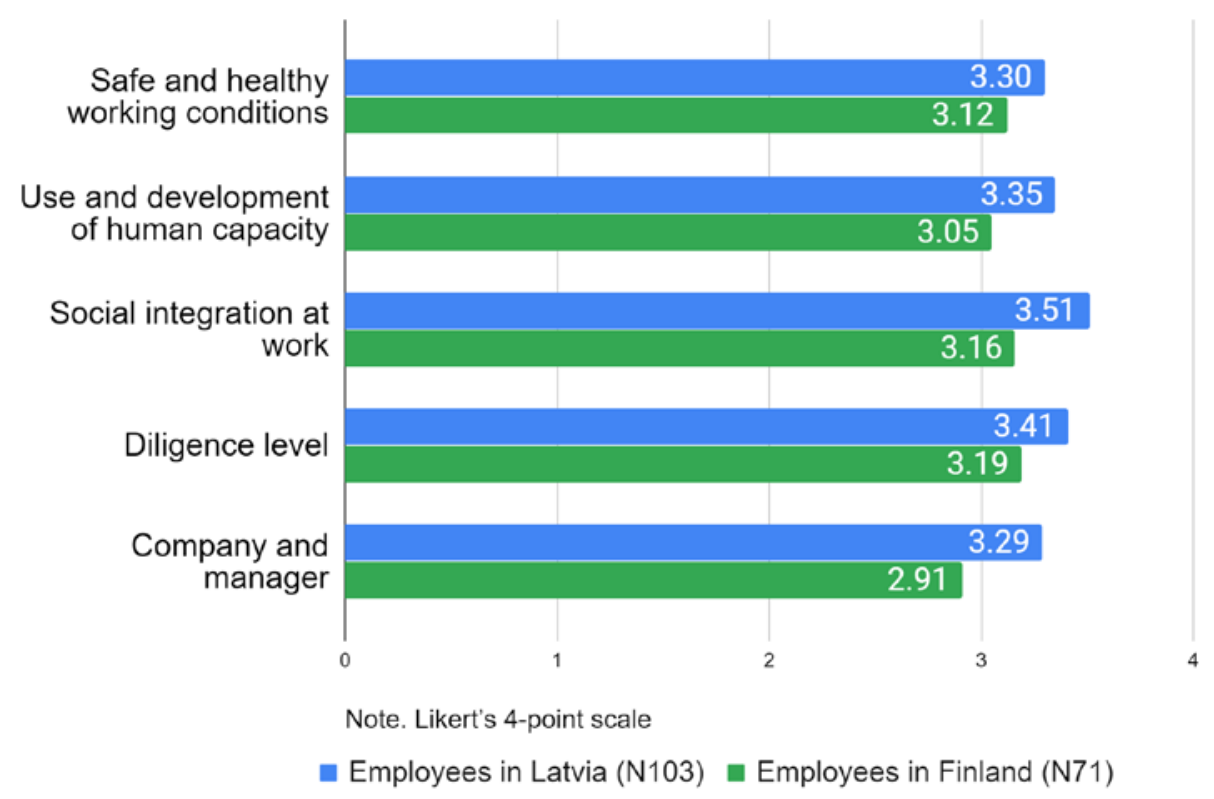

Figure 3 Differences in scales between countries

Employees of Finnish and Latvian companies have given different evaluation in different age groups. Results of Latvian employees show statistically significant differences in statement "Stress at work does not influence my private life" where older employees more often disagree or rather disagree with this statement. Employees of age group 55 and above gave the most negative evaluation in almost all statements. It should be noted that in this age group more than $90 \%$ are employees of Finnish companies. 
Blumberga \& Akmene, 2020. Personnel Work Life Quality and Engagement: Example of a Nordic Business Information Technology Company

Looking at the results regarding seniority significant differences were found in "Safe and healthy working conditions" scale where statistically significant differences were among employees who have worked more than 10 years and those who have worked less than one year and 2 to 5 years. It can be explained with high demands for work environment. Also, significant differences were found in evaluation of statement "My work load is adequate and well balanced". One half of employees with seniority reply that they disagree or rather disagree with the particular statement. These results could be explaining with that longer working employees have more duties and they are expected to be more productive than employees with less experience in the company.

\section{Discussion and conclusions}

Work life quality and engagement measures of both countries included in the research show positive evaluation from personnel which indicates that HR and company management work positively for employees. As regards question of the research about relation of work life quality and engagement results show that there is statistically significant and positive relation between them. Various work life quality factors influence engagement. Social integration at work and evaluation of company and manager are the most connected.

Companies succeed the most with social integration of employees and as a result almost all employees feel that they belong with the company and their team. Teams comprise employees who understand each other and work well together, unity is promoted with events.

For both countries the most challenging is balancing work and private lives of employees. Work stress influences private lives of almost one third of the personnel, and almost one fourth of them cannot rest not thinking about work. It should be noted that work stress can be explained with shortage of workforce that results in shortage of time to complete all tasks, respectively, creating more stress. Authors suggest HR to organize a lecture on time management which would help employees to plan their work day and use time at work more effectively, thus reducing stress and being more productive. Employees with seniority in the company indicate to higher stress at work and less possibilities to balance work and private life. In this case it is suggested to give more responsible duties and reduce the work load of employees with seniority. Companies in Finland are suggested to work on personnel job specifics, change of duties when possible, give interesting tasks with more responsibility. Team leaders together with HR should organize meetings and improve these issues.

One fourth of employees in Latvia and one third in Finland disagree that company involves them in decision making. Finnish employees would evaluate inner communication higher if they felt more involved in decision making. 
Although companies in Finland have strategic approach to events and employee participation, they lack structured feedback. HR is suggested to organize employee involvement in decision making at times spreading short questionnaires on solving some internal questions. Companies in inland should cognize and improve internal communication. Companies of both countries should consider publicly or privately discussing suggestions.

In the different statement of age groups most positive evaluations were given by 18 to 24 -year-old employees. Also, employees aged 45 to 54 consider their work interesting and inspiring. The most negative evaluations were given by employees aged 55 and more; 90\% of them are Finnish. To prevent negative feeling about different aspect of work and workplace HR of Finnish companies are suggested to work more with older employees, consider their work load and reduce work stress by finding out the stressors.

Employees who can use their capacity consider work more meaningful and inspiring, and they spend their work hours more productively, they also have a more energetic approach towards work and are more eager to come to work. Social integration at work makes good relationship among colleagues and more positive atmosphere in team. Meaningful work, team and colleagues, and management decisions promote employee loyalty and liking of their work. It should be noted that seniority is not connected with loyalty.

To maintain positive attitude of employees and improve problematic issues, it is suggested to organize management meetings between countries to exchange implemented measures and feedback. This could save money and time introducing interesting and appropriate measures resulting in higher work life quality and promoting engagement.

\section{References}

Ababneh, O.M.A., \& Macky, K. (2015). The Meaning and Measurement of Employee Engagement: A Review of the Literature. Retrieved from https://www.researchgate.net/ publication/291698308

Alqarni, S.A.Y. (2016). Quality of Work Life as a Predictor of Work Engagement among the Teaching Faculty at King Abdulaziz University. Retrieved from http://www.ijhssnet.com/ journals/Vol_6_No_8_August_2016/14.pdf

Armstrong, M. (2006). A Handbook of Human Resource Management Practice. London: Kogan Page Limited

Bakker, A.B., \& Albrecht, S. (2018). Work engagement: current trends. Career Development International. DOI: https://doi.org/10.1108/CDI-11-2017-0207

Connolly, D. et al. (2017). Work and life: a behavioral approach to solving work-life conflict. Retrieved from https://www.ideas42.org/wp-content/uploads/2017/03/I42-863_RWJ_ Report_DesignSolution_final.pdf

Corporate Leadership Council (2004). Driving Performance and Retention through Employee Engagement. Retrieved from https://www.stcloudstate.edu/humanresources/_files/documents/supv-brownbag/employee- engagement.pdf 
Blumberga \& Akmene, 2020. Personnel Work Life Quality and Engagement: Example of a Nordic Business Information Technology Company

Dixit, A.K., \& Pandiya, S. (2015). Quality of work life- an overview on banking system. Traverse City: Horizon Books.

Fatmasari, E., Mochammad, M., \& Wulida, A.T. (2018). The Effect of Quality of Work-life and Motivation on Employee Engagement with Job Satisfaction as an Intervening Variable. Retrieved from https://rjoas.com/issue-2018-02/article_12.pdf

Geldenhuy, M., Laba, K., \& Venter, C.M. (2015). Meaningful work, work engagement and organizational commitment. Retrieved from https://www.researchgate.net/ publication/266673028

Inda, S.S. (2013). Quality of Work Life. Toronto: Canadian Academic Publishing.

Kanten, S., \& Sadullah, O. (2012). An empirical research on relationship quality of work life and work engagement. Retrieved from https://www.researchgate.net/publication/257716769

Kawemba, J.N. (2010). Quality of Work Life and Job Satisfaction of Academic Staff in Publicuniversities of Uganda. Munich: Grin Publishing.

Lockwood, N.R. (2007). Leveraging Employee Engagement for Competitive Advantage: HR's Strategic Role. SHRM Research. Retrieved from https://pdfs.semanticscholar.org/ acc4/4ab3d4cb3c648cb2993fe705129984440ffe.pdf

Monga, O.P., \& Verma, P. (2015). Understanding Quality of Work Life in Contemporary World. Retrieved from https://www.researchgate.net/publication/275829996

Reddy, L., \& Reddy, M. (2010). Quality of work life of employees: emerging dimensions. Retrieved from http://www.ipublishing.co.in/ajmrvol1no1/EIJMRS1063.pdf

Redmond, K. (2009). Leadership by Engagement: Leading Through Authentic Character to Attract, Retain, and Energize. Ontario: Engagement Publishing.

Schaufeli, W., \& Bakker, A. (2004). Utrecht Work Engagement Scale. Version 1.1. Retrieved from https://www.wilmarschaufeli.nl/publications/Schaufeli/Test\%20Manuals/Test_ manual_UWES_English.pdf

Sharma, N., Chaudhary, N., \& Singh, V.K. (2018). Management Techniques for Employee Engagement in Contemporary Organizations. Hershey: IGI Global.

Srivastava, S., \& Kanpur, R. (2014). A Study on Quality of Work Life: Key Elements \& It's Implications. Retrieved from http://www.iosrjournals.org/iosr-jbm/papers/Vol16issue3/Version-1/H016315459.pdf

Timossi, L.S. et al. (2008). Evaluation of quality of work life: an adaptation from the Walton's qwl model. Retrieved from https://www.researchgate.net/publication/285277309

Walton, R.E. (1973). Quality of work life: what is it? Sloan Management Review. Retrieved from https://is.gd/HC2Luw 